Francesc Torres-Tamarit, Kathrin Linke and Marc van Oostendorp (Eds.) Approaches to Metaphony in the Languages of Italy 


\section{Phonology and Phonetics}

Editor

Aditi Lahiri

Volume 20 


\section{Approaches to Metaphony in the Languages of Italy}

Edited by

Francesc Torres-Tamarit, Kathrin Linke and Marc van Oostendorp

DE GRUYTER

MOUTON 
ISBN 978-3-11-036956-4

e-ISBN (PDF) 978-3-11-036631-0

e-ISBN (EPUB) 978-3-11-039327-9

ISSN 1861-4191

\section{Library of Congress Cataloging-in-Publication Data}

A CIP catalog record for this book has been applied for at the Library of Congress.

\section{Bibliographic information published by the Deutsche Nationalbibliothek}

The Deutsche Nationalbibliothek lists this publication in the Deutsche Nationalbibliografie; detailed bibliographic data are available on the Internet at http://dnb.dnb.de.

(C) 2016 Walter de Gruyter GmbH, Berlin/Boston

Typesetting: Compuscript Ltd., Shannon, Ireland

Printing and binding: CPI books $\mathrm{GmbH}$, Leck

(2) Printed on acid-free paper

Printed in Germany

www.degruyter.com 